of Hückel's paper. Its purpose was rather merely to show that for the influence of different groups on simple substitution reactions in benzene a simple and intuitive interpretation without detailed assumptions about the mechanism of reaction can be given by means of the quantum theoretical calculation of the distortion of the electronic distribution in the benzene ring produced by the substituent.

Institut für theoretische Physik ERICH HüCKEL.

der Technischen Hochschule, Stuttgart.

Chemisches Institut der Universität,

WALTER HÜCKel. Greifswald.

1 Nature, 129, $278 ; 1932$.

2. Physik, 72, $310 ; 1931$.

- See, for example, Fries und Schimmelschmidt, Ann. d. Chem., 484, $245 ; 1930$.

\section{Sulphur Assimilation in Wool Growth}

IN a series of important papers dealing with 'Bush sickness' of ruminants in New Zealand, T. Rigg ${ }^{1}$ and his co-workers at the Cawthron Institute, following on the work of B. C. Aston, ${ }^{2}$ established the incidence of this ailment as due to iron deficiency in well-marked localities recognised as 'unhealthy'. So far as the pasturage on bealthy and unhealthy areas is concerned, the average seasonal iron content is practically the same. The soil-iron content, however, is in general far greater in the healthy areas; and in the one comparative case where the total iron is actually higher in the unhealthy area, the 5 per cent oxalic acid soluble iron (a rough measure of relative availability) is only one-fourth of that in the healthy area.

From these investigations emerges the startling but apparently unassailable conclusion that ingested soil is an absolutely essential supplement to the pasturage, which in itself, in clean condition, is definitely irondeficient in all these sheep-rearing areas. The habit of the sheep of ingesting soil has thus provided Rigg with an interesting interpretation of the incidence of the similar 'pining' sickness of Cheviots, which was unknown when the land was overrun with moles, but made its appearance when the moles were exterminated.

These investigations are also highly significant in relation to the associated nutritional problem of the excessive cystine yield in wool growth compared with the cystine available in normal diet.

To quote Rigg's own words, " an interesting and unexpected result was the great improvement both in growth and in lustre and elasticity of the new wool grown after administration of ferric ammonium citrate. It seems possible, therefore, that 'iron' plays some special rôle in wool growth. Is it possible that the wonderful results in increased wool growth obtained through the provision of a 'lick' of blood meal in the Meteor Downs experiment in Queensland may be due partly to the iron content of the blood meal (approximately 0.2 per cent)? It does not seem probable that the great increase in wool growth (averaging $20 \mathrm{oz}$. per sheep) was wholly due to the small amount of cystine administered in this way."

Accepting Evans's values ${ }^{3}$ for the cystine contents of pastures, it is self-evident that conversion of noncystine sulphur into cystine must occur, and one means of such conversion may be dependent upon invigorated action of intestinal bacteria, as recently suggested by Dr. Rimington and Mr. Bekker, ${ }^{4}$

Equally evident is the probability that adventitious sulphur as well as adventitious iron may be an essential supplement to the food-stuff. Soil ingestion in the areas investigated by Rigg, which are of volcanic origin and almost exclusively silicious in character, would not appreciably affect the sulphur intake, yet with the iron supplement not only do the general anæmic symptoms of bush sickness disappear, but, also, the wool, which practically ceases to grow in severe cases, resumes normal growth and lustre, with a well-defined 'break' coincident with the remedial treatment. Pasturage from such soils may well prove to be deficient even in total sulphur (though evidence on this point is lacking). In this event, the stockwater supply, particularly from artesian wells, may assume a special significance.

Evident again is the sweeping conclusion that the view hitherto widely accepted, which regarded the cystine supply as the essential limiting factor in wool production, is now definitely exploded, and that the various attempts to influence wool growth directly by administering cystine-rich fodder were foredoomed to failure.

The situation has thus radically changed since 1927, when I first pointed out the significance of the variable sulphur content of wool in its histological, nutritional, and technical aspects. ${ }^{5}$ The extensive scheme of research developed from this, in conjunction with my present and past colleagues and co-workers, Mr. Barritt, ${ }^{6}$ Dr. Rimington, ${ }^{7}$ and Mr. Bekker, ${ }^{8}$ did in fact include an attempt to influence the sulphur content of rabbit wool by addition of varied doses of cystine and of wool hydrolysate, to a standard ration. ${ }^{9}$ It was clear from these experiments that the seasonal factor completely masked any possible cystine effect, a difference of as much as 18 per cent in the sulphur content of wool from the same animal between one three months' clip and the next being found equally in the cystine-fed and control animals.

It was, moreover, further observed by Mr. Barritt and Dr. Rimington ${ }^{7}$ that the increased sulphur yield was still wholly in the form of cystine.

While the recent developments do not lessen but rather emphasise the importance of the work on sulphur content in relation to wool quality, initiated in these laboratories, they expose the dubiety of attempts to associate with a supposedly specific diet supplement, divergent effects from those obtained with a basal diet control. In view of the abovementioned and possibly other as yet unrecognised factors, field-work data especially would appear to need very careful consideration before recommendations are made to pastoralists on nutritional methods of improving wool growth and quality.

A. T. KING

(Chief Chemist).

The Chemical Laboratories,

Wool Industries Research Assocn., Torridon, Headingley, Leeds.

1 Rigg and others, N.Z. Dept. of Scientific and Industrial Research, Bulletin, No. $32 ; 1932$

Aston, Trans. N.Z. Inst., 58, 536 ; 1928, and later papers.

Evans, J. Agric. Science, 21, 806 ; 1931.

Rimington and Bekker, NATURE, 129, 687, May 7, 1932

5 King, J. Text. Inst., 18, $364 \mathrm{~T}$; 1927 . Text. Merc., Oct. 23,17 1929.

Barritt and King, J. Text. Inst., 17, 386T ; 1926: 20, 151T; 1929. Biochem. J., 25, 1075; i931.

? Barritt and Rimington, Biochem. J., 25, 1072 ; 1931.

- Bekker and King, Biochem. J., 25, 1077; 1931.

- Barritt, King, and Pickard, Biochem. J.,'24, 1061 ; 1930.

\section{Constitution of the Keratin Molecule}

OF the two comments which Dr. Rimington ${ }^{1}$ has to make on our recent note ${ }^{2}$ regarding the constitution of the keratin molecule, one is erroneous and the other misleading. In our original communication, we claim to have shown that the amount of free amino

No. 3269 , VoL. 129] 